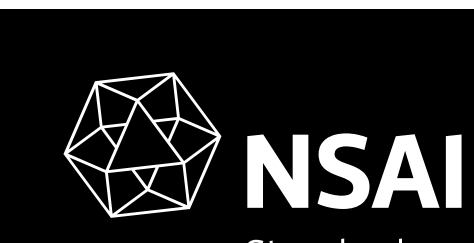

Standards

Irish Standard

I.S. EN 60193:2000

Hydraulic turbines, storage pumps and pump-turbines Model acceptance tests (IEC 60193:1999) 


\section{I.S. EN 60193:2000}

Incorporating amendments/corrigenda issued since publication:

The National Standards Authority of Ireland (NSAI) produces the following categories of formal documents:

I.S. xxx: $\quad$ Irish Standard - national specification based on the consensus of an expert panel and subject to public consultation.

S.R. xxx: $\quad$ Standard Recommendation - recommendation based on the consensus of an expert panel and subject to public consultation.

SWiFT xxx: A rapidly developed recommendatory document based on the consensus of the participants of an NSAI workshop.

This document replaces/revises/consolidates the NSA/ adoption of the document(s)

indicated on the CEN/CENELEC cover/Foreword and the following National document(s):

NOTE: The date of any NSAI previous adoption may not match the date of its

original CEN/CENELEC document.

This document is based on: $\quad$ Published:

EN 60193:1999 9 December, 1999

This document was published

ICS number:

under the authority of the NSAI

27.140

and comes into effect on:

16 June, 2000

NSAI

1 Swift Square, Northwood, Santry

Dublin 9
$\mathrm{T}+35318073800$

$\mathrm{F}+35318073838$

E standards@nsai.ie

W NSAI.ie
Sales:

$\mathrm{T}+35318576730$

$\mathrm{F}+35318576729$

W standards.ie

Údarás um Chaighdeáin Náisiúnta na hÉireann 


\section{EUROPEAN STANDARD \\ NORME EUROPÉENNE \\ EUROPÄISCHE NORM}

EN 60193

December 1999

$\operatorname{ICS} 27.140$

Supersedes EN 60995:1994

English version

\section{Hydraulic turbines, storage pumps and pump-turbines \\ Model acceptance tests \\ (IEC 60193:1999)}

Turbines hydrauliques, pompes

d'accumulation et pompes-turbines

Essais de réception sur modèle

(CEI 60193:1999)
Hydraulische Turbinen, Speicherpumpen und Pumpturbinen Modellabnahmeprüfungen (IEC 60193:1999)

This European Standard was approved by CENELEC on 1999-12-01. CENELEC members are bound to comply with the CEN/CENELEC Internal Regulations which stipulate the conditions for giving this European Standard the status of a national standard without any alteration.

Up-to-date lists and bibliographical references concerning such national standards may be obtained on application to the Central Secretariat or to any CENELEC member.

This European Standard exists in three official versions (English, French, German). A version in any other language made by translation under the responsibility of a CENELEC member into its own language and notified to the Central Secretariat has the same status as the official versions.

CENELEC members are the national electrotechnical committees of Austria, Belgium, Czech Republic, Denmark, Finland, France, Germany, Greece, Iceland, Ireland, Italy, Luxembourg, Netherlands, Norway, Portugal, Spain, Sweden, Switzerland and United Kingdom.

\section{CENELEC}

European Committee for Electrotechnical Standardization

Comité Européen de Normalisation Electrotechnique

Europäisches Komitee für Elektrotechnische Normung

Central Secretariat: rue de Stassart 35, B - 1050 Brussels

(c) 1999 CENELEC - All rights of exploitation in any form and by any means reserved worldwide for CENELEC members. 


\section{I.S. EN 60193:2000}

Page 2

EN 60193:1999

\section{Foreword}

The text of document 4/157/FDIS, future edition 2 of IEC 60193 , prepared by IEC TC 4 , Hydraulic turbines, was submitted to the IEC-CENELEC parallel vote and was approved by CENELEC as EN 60193 on 1999-12-01.

This European Standard supersedes EN 60995:1994.

The following dates were fixed:

- latest date by which the EN has to be implemented at national level by publication of an identical national standard or by endorsement

- latest date by which the national standards conflicting with the EN have to be withdrawn

Annexes designated "normative" are part of the body of the standard.

Annexes designated "informative" are given for information only.

In this standard, annexes $B, F, G, K, L, M$ and $Z A$ are normative and annexes $A, C, D, E, H$, $\mathrm{J}, \mathrm{N}$ and $\mathrm{P}$ are informative.

Annex ZA has been added by CENELEC.

\section{Endorsement notice}

The text of the International Standard IEC 60193:1999 was approved by CENELEC as a European Standard without any modification. 


\section{Annex ZA (normative) \\ Normative references to international publications with their corresponding European publications}

This European Standard incorporates by dated or undated reference, provisions from other publications. These normative references are cited at the appropriate places in the text and the publications are listed hereafter. For dated references, subsequent amendments to or revisions of any of these publications apply to this European Standard only when incorporated in it by amendment or revision. For undated references the latest edition of the publication referred to applies (including amendments).

NOTE: When an international publication has been modified by common modifications, indicated by (mod), the relevant $\mathrm{EN} / \mathrm{HD}$ applies.

\begin{tabular}{|c|c|c|}
\hline Publication & Year & $\underline{\text { Title }}$ \\
\hline IEC 60041 (mod) & 1991 & $\begin{array}{l}\text { Field acceptance tests to determine the } \\
\text { hydraulic performance of hydraulic turbines, } \\
\text { storage pumps and pump-turbines }\end{array}$ \\
\hline IEC 60609 & 1978 & $\begin{array}{l}\text { Cavitation pitting evaluation in hydraulic } \\
\text { turbines, storage pumps and pump-turbines }\end{array}$ \\
\hline IEC $60609-2$ & 1997 & Part 2: Evaluation in Pelton turbines \\
\hline IEC 60994 & 1991 & $\begin{array}{l}\text { Guide for field measurement of vibrations } \\
\text { and pulsations in hydraulic machines } \\
\text { (turbines, storage pumps and } \\
\text { pump-turbines) }\end{array}$ \\
\hline JEC 61364 & 1999 & Nomenclature for hydroelectric machinery \\
\hline IEC 61366 & series & $\begin{array}{l}\text { Hydraulic turbines, storage pumps and } \\
\text { pump-turbines - Tendering Documents }\end{array}$ \\
\hline ISO $31-3$ & 1992 & $\begin{array}{l}\text { Quantities and units } \\
\text { Part 3: Mechanics }\end{array}$ \\
\hline ISO $31-12$ & 1992 & Part 12: Characteristic numbers \\
\hline ISO 468 & 1982 & $\begin{array}{l}\text { Surface roughness - Parameters, their } \\
\text { values and general rules for specifying } \\
\text { requirements }\end{array}$ \\
\hline ISO $1438-1$ & 1980 & $\begin{array}{l}\text { Water flow measurement in open channels } \\
\text { using weirs and Venturi flumes } \\
\text { Part 1: Thin-plate weirs }\end{array}$ \\
\hline ISO 2186 & 1973 & $\begin{array}{l}\text { Fluid flow in closed conduits } \\
\text { Connections for pressure signal } \\
\text { transmissions between primary and } \\
\text { secondary elements }\end{array}$ \\
\hline $\begin{array}{l}\text { ISO } 2533 \\
\text { A1 }\end{array}$ & $\begin{array}{l}1975 \\
1985\end{array}$ & Standard atmosphere \\
\hline
\end{tabular}

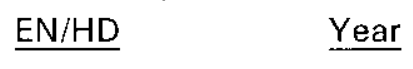

EN 60041 1994

EN 60609-2 1999

EN 60994 1992 


\section{I.S. EN 60193:2000}

Page 4

EN 60193:1999

\begin{tabular}{|c|c|c|c|c|}
\hline Publication & Year & Title & $\underline{\mathrm{EN} / \mathrm{HD}}$ & Year \\
\hline ISO 4006 & 1991 & $\begin{array}{l}\text { Measurement of fluid flow in closed } \\
\text { conduits - Vocabulary and symbols }\end{array}$ & EN 24006 & 1993 \\
\hline ISO 4185 & 1980 & $\begin{array}{l}\text { Measurement of liquid flow in closed } \\
\text { conduits - Weighing method }\end{array}$ & EN 24185 & 1993 \\
\hline ISO 4373 & 1995 & $\begin{array}{l}\text { Measurement of liquid flow in open } \\
\text { channels - Water-level measuring devices }\end{array}$ & - & - \\
\hline ISO $5167-1$ & 1991 & $\begin{array}{l}\text { Measurement of fluid flow by means of } \\
\text { pressure differential devices - Part 1: Orifice } \\
\text { plates, nozzles and Venturi tubes inserted in } \\
\text { circular cross-section conduits running full }\end{array}$ & - & - \\
\hline ISO 5168 & 1978 & $\begin{array}{l}\text { Measurement of fluid flow - Estimation of } \\
\text { uncertainly of a flow-rate measurement }\end{array}$ & - & - \\
\hline ISO 6817 & 1992 & $\begin{array}{l}\text { Measurement of conductive liquid flow in } \\
\text { closed conduits - Method using } \\
\text { electromagnetic flowmeters }\end{array}$ & EN ISO 6817 & 1995 \\
\hline ISO $7066-1$ & 1997 & $\begin{array}{l}\text { Assessment of uncertainty in calibration and } \\
\text { use of flow measurement devices } \\
\text { Part 1: Linear calibration relationships }\end{array}$ & - & - \\
\hline ISO $7066-2$ & 1988 & Part 2: Non-linear calibration relationships & - & - \\
\hline ISO 8316 & 1987 & $\begin{array}{l}\text { Measurement of liquid flow in closed } \\
\text { conduits - Method by collection of the liquid } \\
\text { in a volumetric tank }\end{array}$ & EN ISO 8316 & 1995 \\
\hline ISO 9104 & 1991 & $\begin{array}{l}\text { Measurement of fluid flow in closed } \\
\text { conduits - Methods of evaluating the } \\
\text { performance of electromagnetic flow-meters } \\
\text { for liquids }\end{array}$ & EN 29104 & 1993 \\
\hline VIM & 1993 & $\begin{array}{l}\text { International vocabulary of basic and } \\
\text { general terms in metrology } \\
\text { (BIPM-IEC-ISO-OIML) }\end{array}$ & - & - \\
\hline
\end{tabular}




\section{INTERNATIONAL STANDARD}

\section{IEC 60193}

Second edition

1999-11

Hydraulic turbines, storage pumps

and pump-turbines -

Model acceptance tests

This English-language version is derived from the original bilingual publication by leaving out all French-language pages. Missing page numbers correspond to the Frenchlanguage pages. 


\section{I.S. EN 60193:2000}

\section{Publication numbering}

As from 1 January 1997 all IEC publications are issued with a designation in the 60000 series. For example, IEC 34-1 is now referred to as IEC 60034-1.

\section{Consolidated editions}

The IEC is now publishing consolidated versions of its publications. For example, edition numbers $1.0,1.1$ and 1.2 refer, respectively, to the base publication, the base publication incorporating amendment 1 and the base publication incorporating amendments 1 and 2 .

\section{Further information on IEC publications}

The technical content of IEC publications is kept under constant review by the IEC, thus ensuring that the content reflects current technology. Information relating to this publication, including its validity, is available in the IEC Catalogue of publications (see below) in addition to new editions, amendments and corrigenda. Information on the subjects under consideration and work in progress undertaken by the technical committee which has prepared this publication, as well as the list of publications issued, is also available from the following:

- IEC Web Site (www.iec.ch)

- Catalogue of IEC publications

The on-line catalogue on the IEC web site (www.iec.ch/searchpub) enables you to search by a variety of criteria including text searches, technical committees and date of publication. On-line information is also available on recently issued publications, withdrawn and replaced publications, as well as corrigenda.

\section{- IEC Just Published}

This summary of recently issued publications (www.iec.ch/online news/ justpub) is also available by email. Please contact the Customer Service Centre (see below) for further information.

\section{- Customer Service Centre}

If you have any questions regarding this publication or need further assistance, please contact the Customer Service Centre:

Email: custserv@iec.ch

Tel: $\frac{+41229190211}{+41229190300}$

Fax: $\quad+41229190300$ 


\section{INTERNATIONAL STANDARD}

\section{IEC 60193}

Second edition

1999-11

Hydraulic turbines, storage pumps

and pump-turbines -

Model acceptance tests

C) IEC 1999 Copyright - all rights reserved

No part of this publication may be reproduced or utilized in any form or by any means, electronic or mechanical, including photocopying and microfilm, without permission in writing from the publisher. 


\section{I.S. EN 60193:2000}

\section{CONTENTS}

Page

FOREWORD

Clause

1 General rules

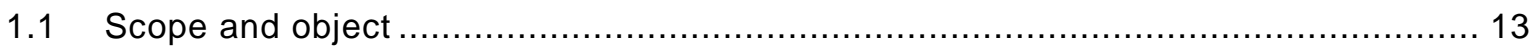

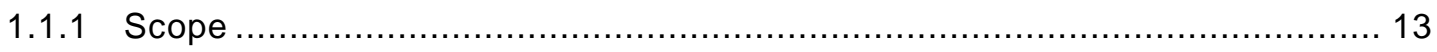

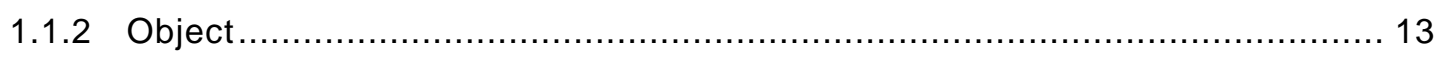

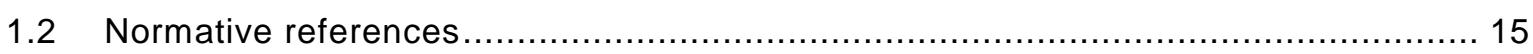

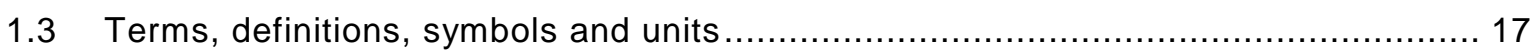

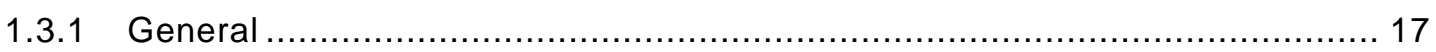

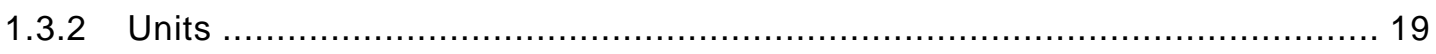

1.3.3 List of terms, definitions, symbols and units ......................................... 21

1.4 Nature and extent of guarantees related to hydraulic performance ......................... 59

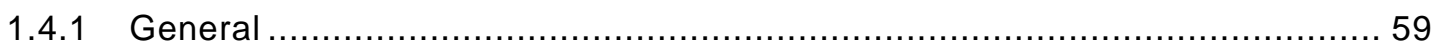

1.4.2 Main hydraulic performance guarantees verifiable by model test ................6 61

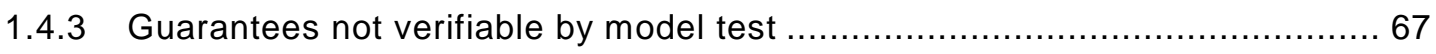

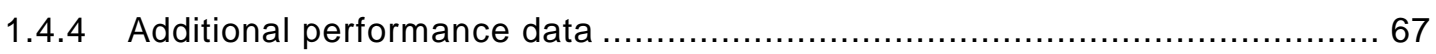

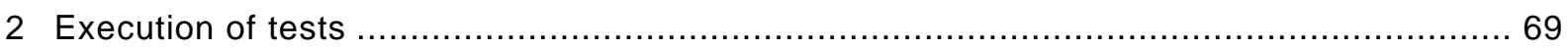

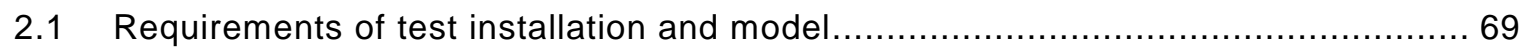

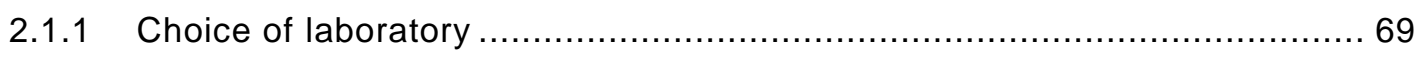

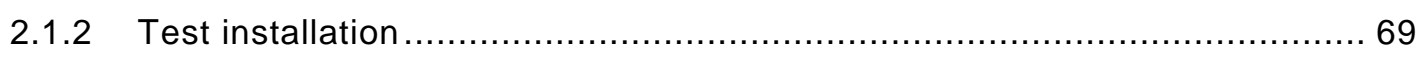

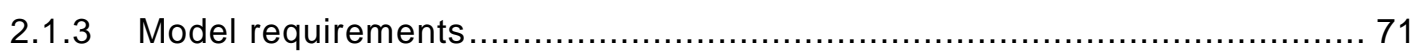

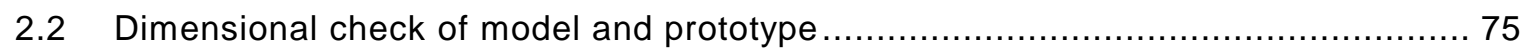

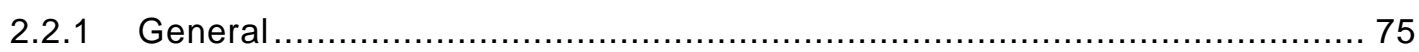

2.2.2 Dimensions of model and prototype to be checked.............................. 95

2.2.3 Surface waviness and roughness.......................................................111

2.3 Hydraulic similitude, test conditions and test procedures..................................119

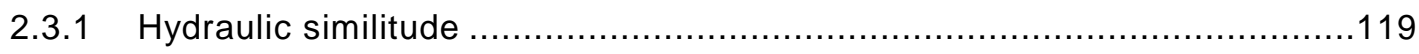

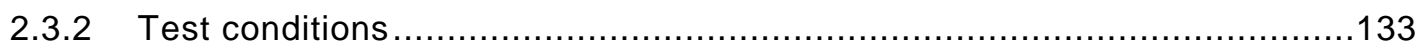

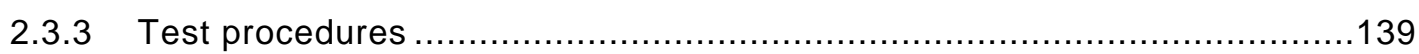

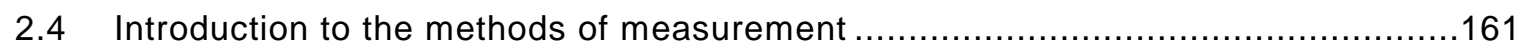

2.4.1 Measurements related to the main hydraulic performance guarantees.......161

2.4.2 Measurements related to additional data.............................................165

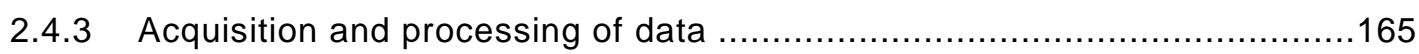

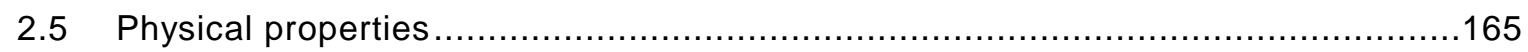

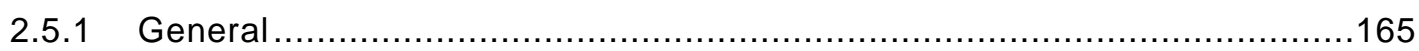

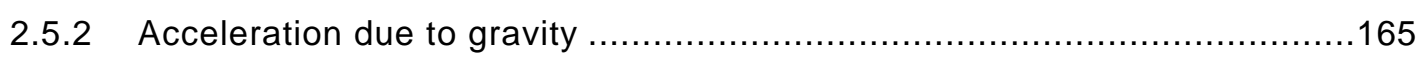

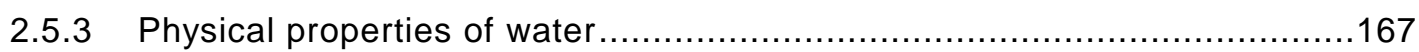

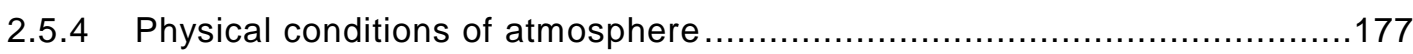

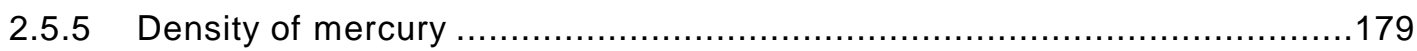




\section{I.S. EN 60193:2000}

60193 @ IEC:1999

Clause

3 Main hydraulic performances: methods of measurement and results

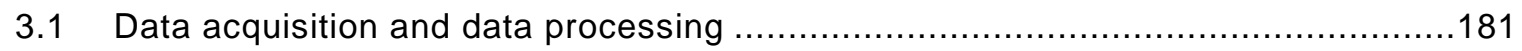

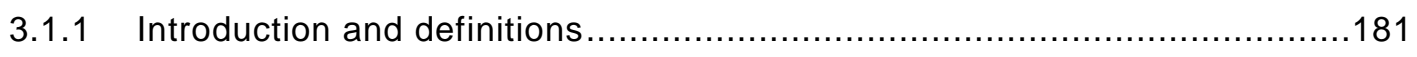

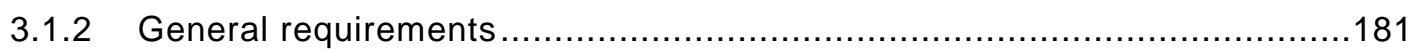

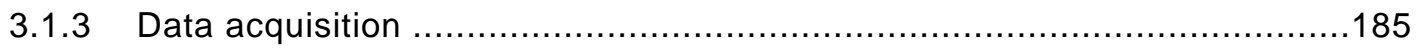

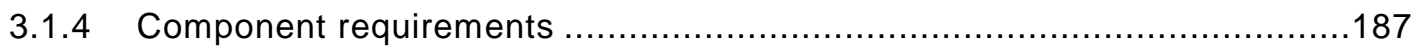

3.1.5 Check of the data acquisition system .........................................193

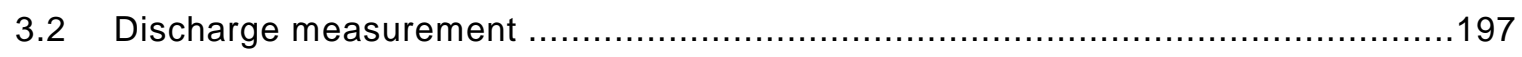

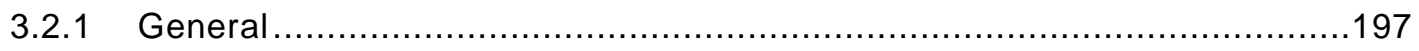

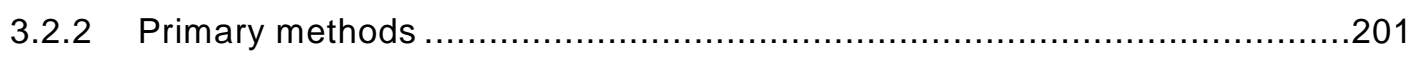

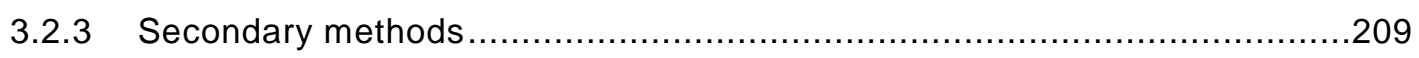

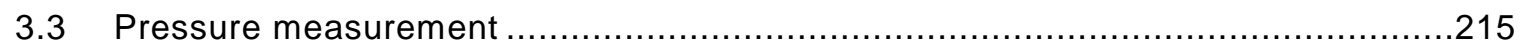

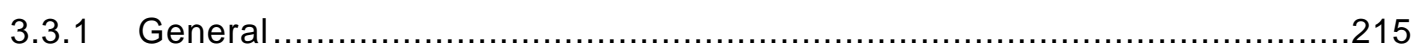

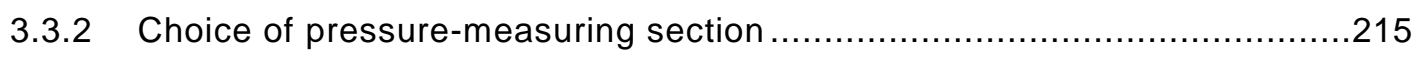

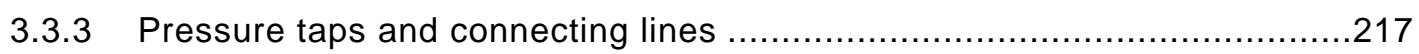

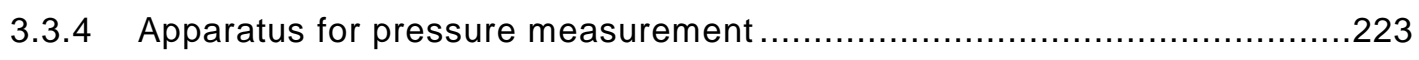

3.3.5 Calibration of pressure measurement apparatus ...................................237

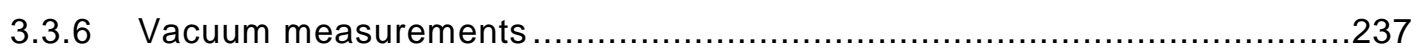

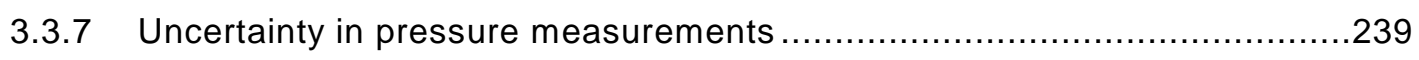

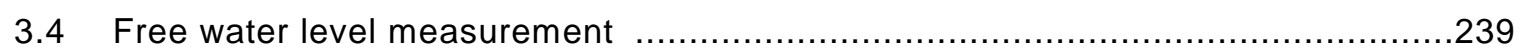

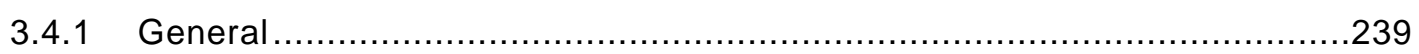

3.4.2 Choice of water level measuring sections .......................................239

3.4.3 Number of measuring points in a measuring section .............................239

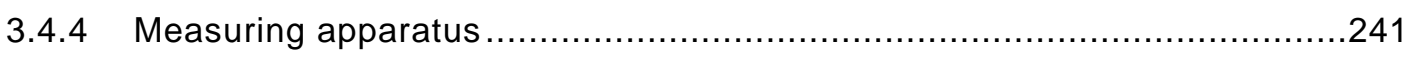

3.4.5 Uncertainty in free water level measurement ....................................245

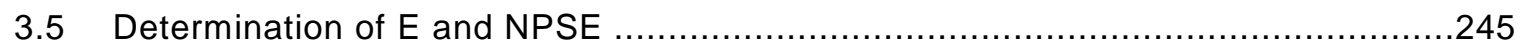

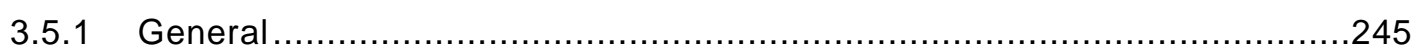

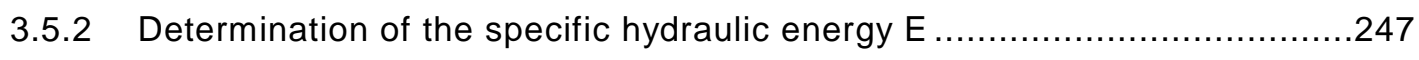

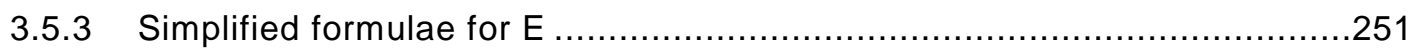

3.5.4 Determination of the net positive suction specific energy NPSE ................261

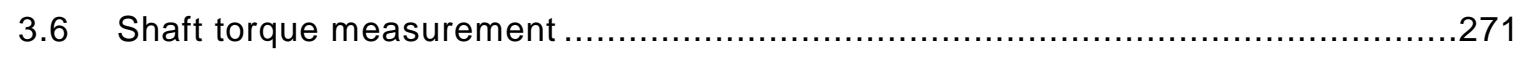

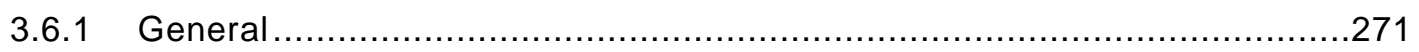

3.6.2 Methods of torque measurement .....................................................271

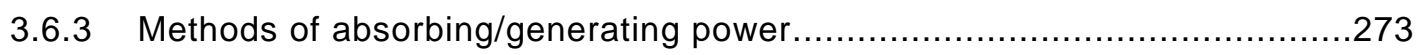

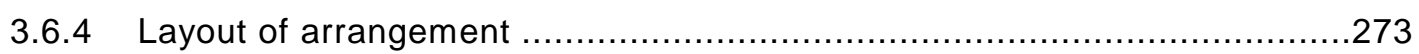

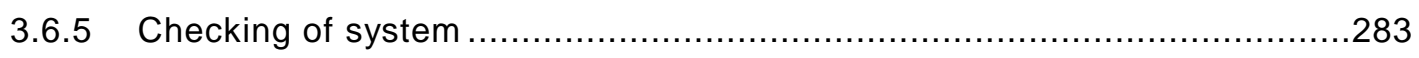

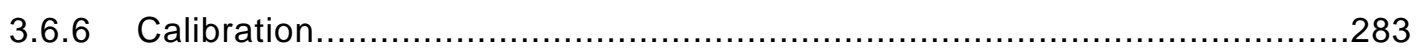

3.6.7 Uncertainty in torque measurement .............................................285

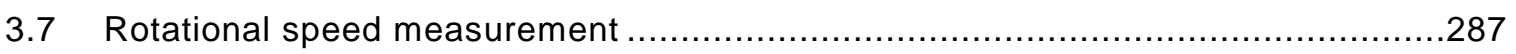

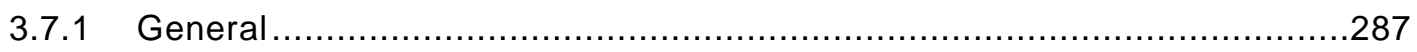

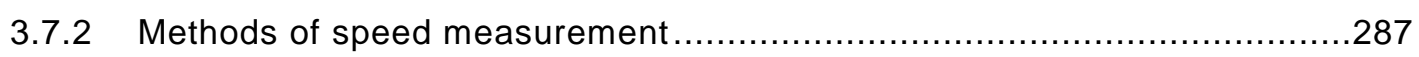

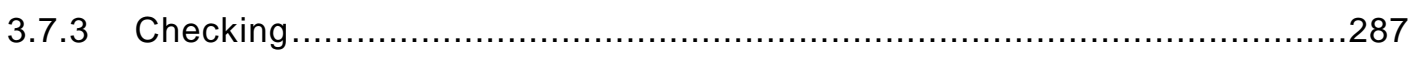

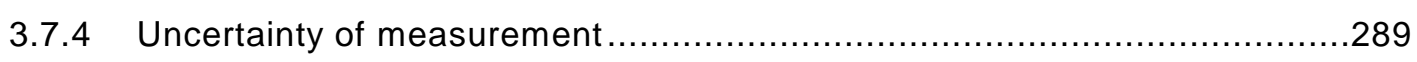




\section{I.S. EN 60193:2000}

60193 @ IEC:1999

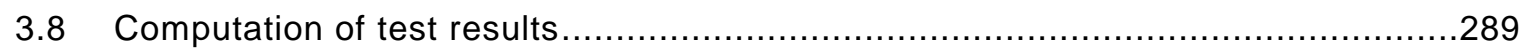

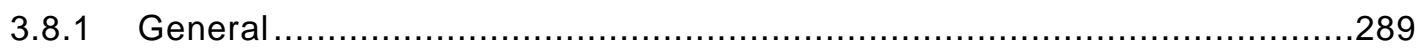

3.8.2 Computation of power, discharge and efficiency in the guarantee range ....299

3.8.3 Computation of steady-state runaway speed and discharge ....................329

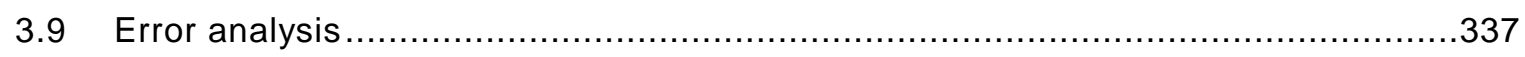

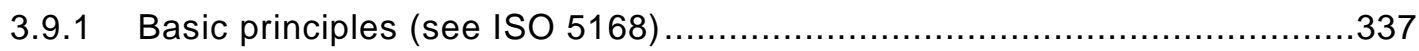

3.9.2 Determination of uncertainties in model tests .......................................341

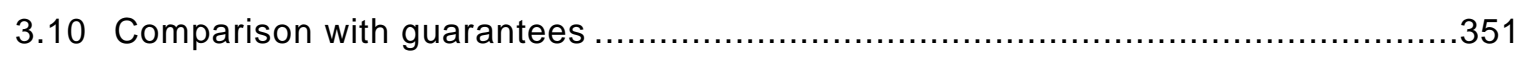

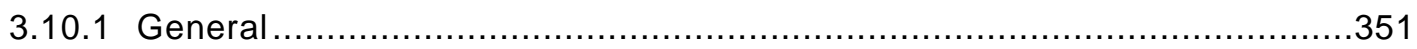

3.10.2 Interpolation curve and total uncertainty bandwidth ...............................353

3.10.3 Power, discharge and/or specific hydraulic energy and efficiency in the

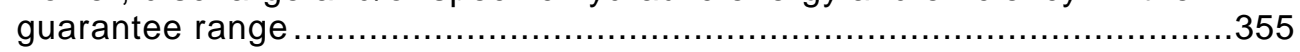

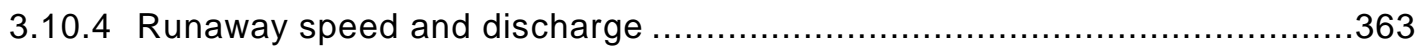

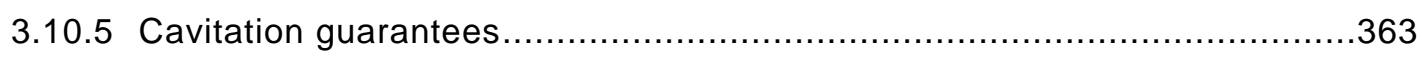

4 Additional performance data - Methods of measurement and results ...........................367

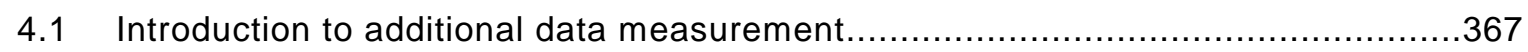

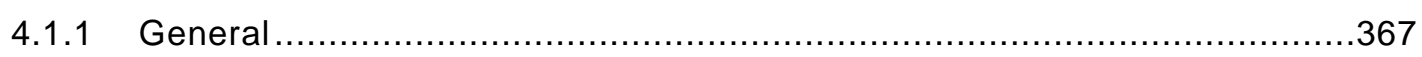

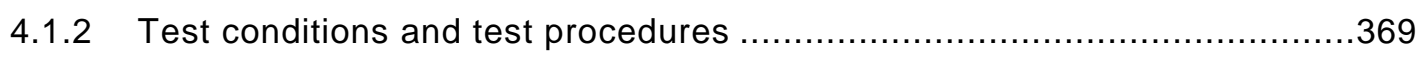

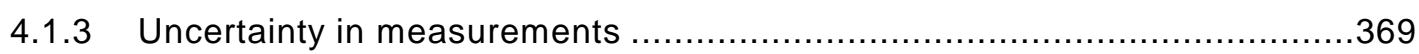

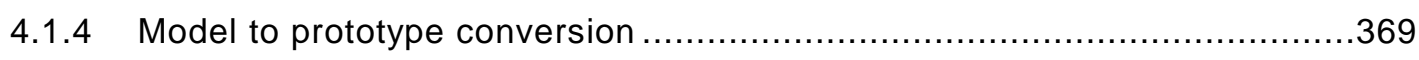

4.2 Data acquisition and processing for measurement of fluctuating quantities ...........371

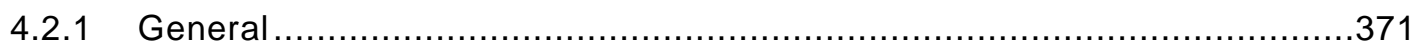

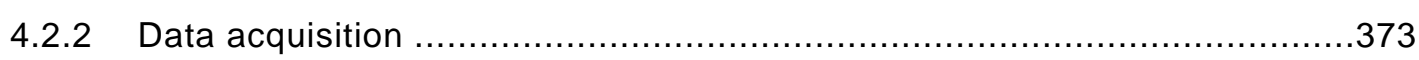

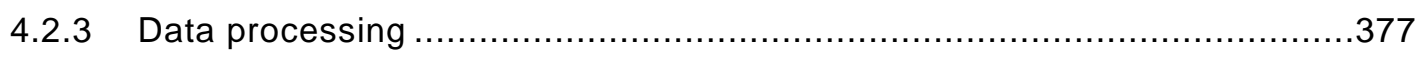

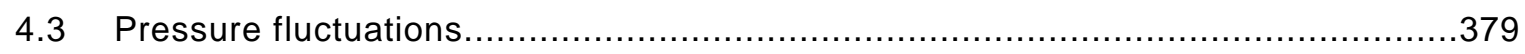

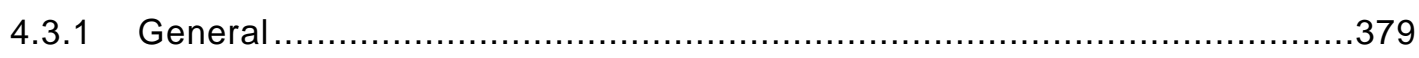

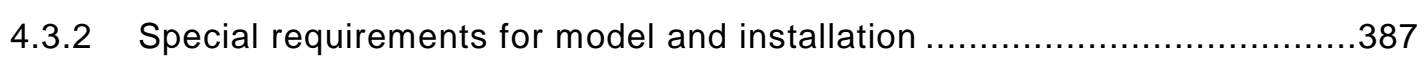

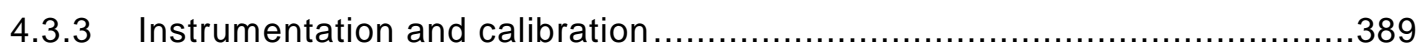

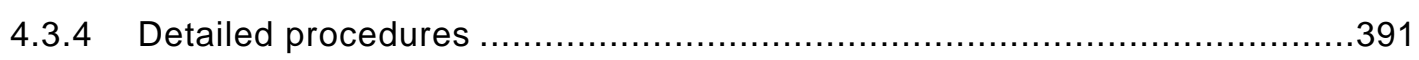

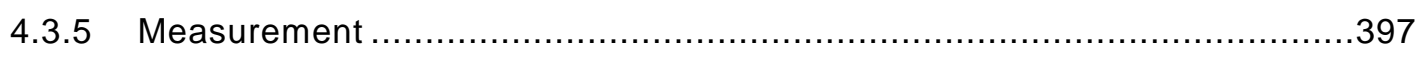

4.3.6 Analysis, presentation and interpretation of results ................................397

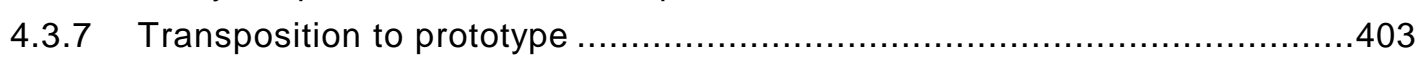

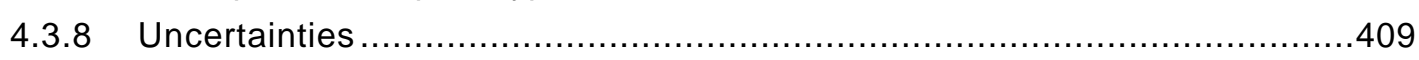

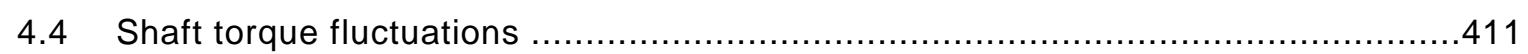

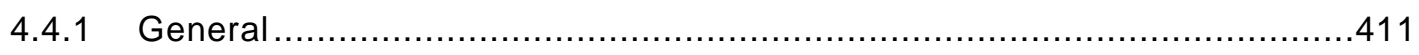

4.4.2 Recommendations for measurement ............................................ 411

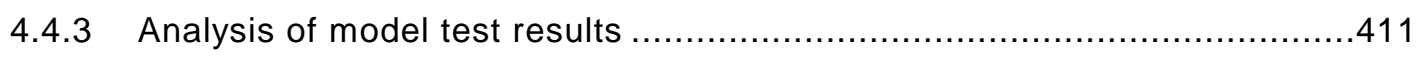

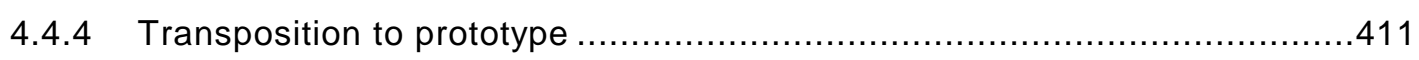

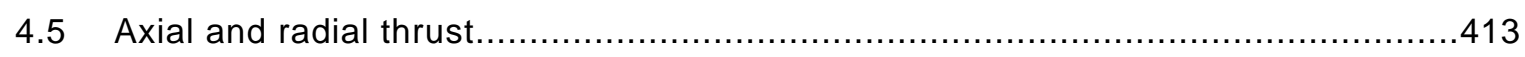

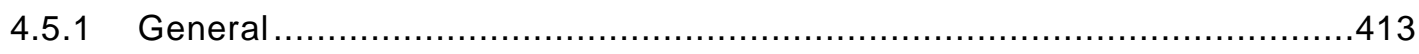

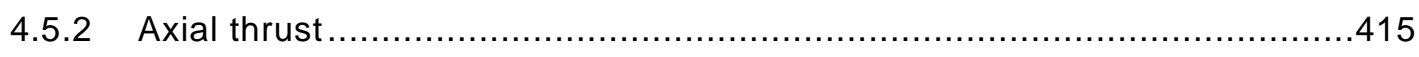

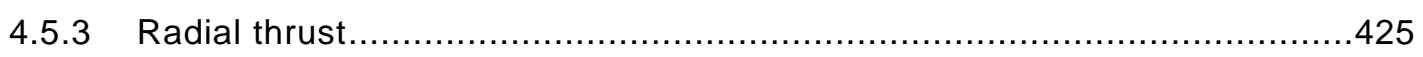




\section{I.S. EN 60193:2000}

60193 @ IEC:1999

4.6 Hydraulic loads on control components

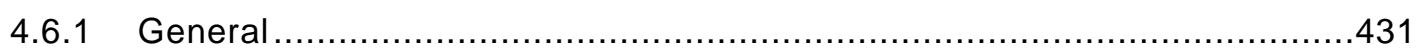

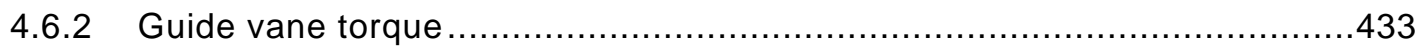

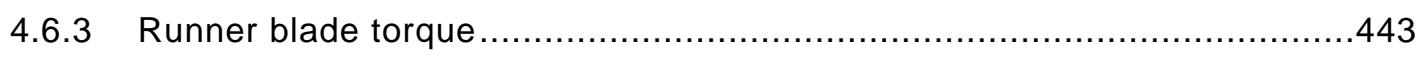

4.6.4 Pelton needle force and deflector torque ..........................................453

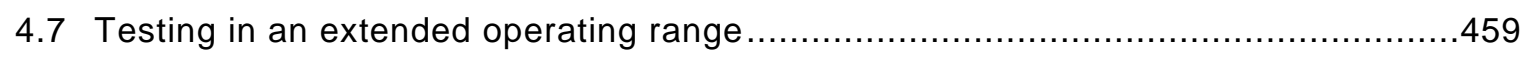

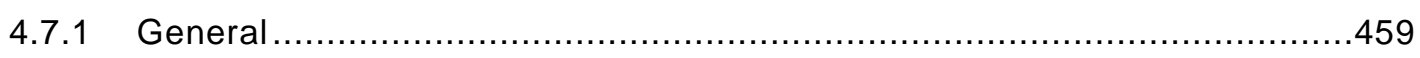

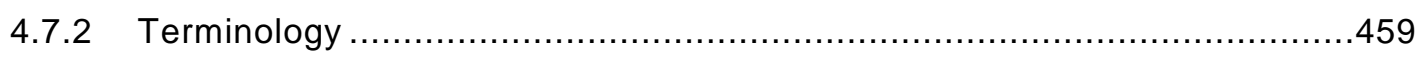

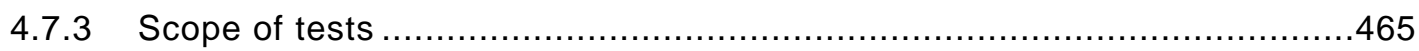

4.7.4 Provisions for particular tests .........................................................467

4.8 Differential pressure measurement in view of prototype index test .......................471

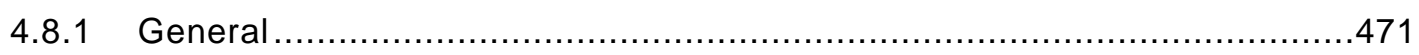

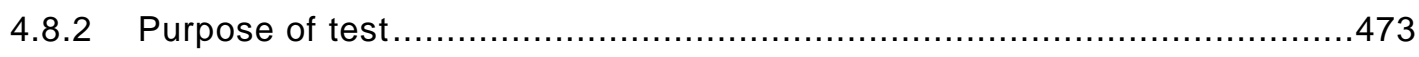

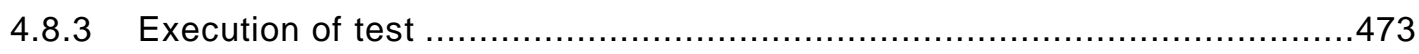

4.8.4 Transposition to prototype conditions ...............................................475

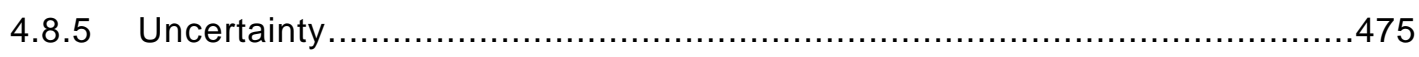

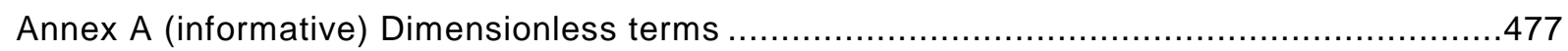

Annex B (normative) Physical properties, data ....................................................... 479

Annex $C$ (informative) Derivation of the equation for the specific hydraulic energy

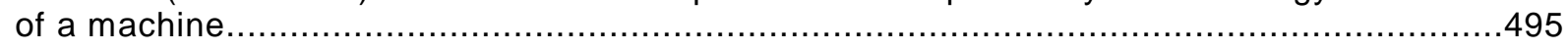

Annex $D$ (informative) Influence of the density of actual water $\rho_{\mathrm{wa}}$ on measurement

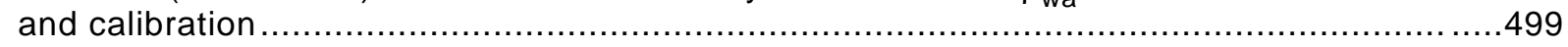

Annex E (informative) Summarized test and calculation procedure ....................................501

Annex $F$ (normative) Scale-up of the hydraulic efficiency of reaction machines .....................509

Annex $G$ (normative) Computation of the prototype runaway characteristics taking into

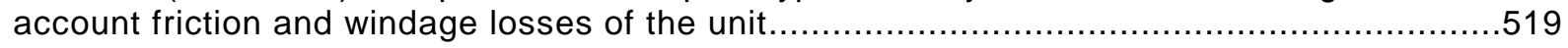

Annex $\mathrm{H}$ (informative) Example of determination of the best smooth curve: method

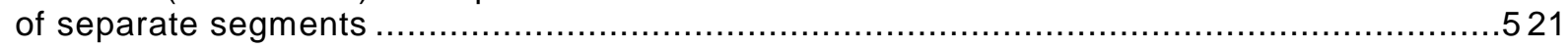

Annex $\mathrm{J}$ (informative) Examples analysis of sources of error and uncertainty evaluation .......527

Annex K (normative) Efficiency scale-up for Pelton turbines .............................................539

Annex $L$ (normative) Analysis of random uncertainties for a test at constant operating

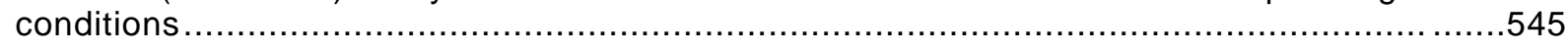

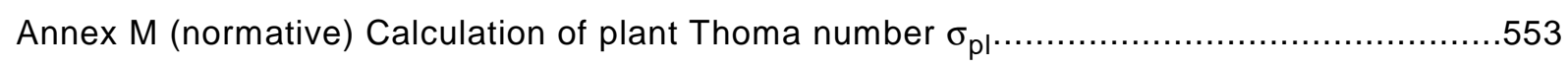

Annex N (informative) Detailed flux diagram of specific hydraulic energy, flow and power .....561

Annex $\mathrm{P}$ (informative) Bibliography 


\title{
INTERNATIONAL ELECTROTECHNICAL COMMISSION
}

\author{
HYDRAULIC TURBINES, STORAGE PUMPS \\ AND PUMP-TURBINES - \\ MODEL ACCEPTANCE TESTS
}

\section{FOREWORD}

1) The IEC (International Electrotechnical Commission) is a worldwide organization for standardization comprising all national electrotechnical committees (IEC National Committees). The object of the IEC is to promote international co-operation on all questions concerning standardization in the electrical and electronic fields. To this end and in addition to other activities, the IEC publishes International Standards. Their preparation is entrusted to technical committees; any IEC National Committee interested in the subject dealt with may participate in this preparatory work. International, governmental and non-governmental organizations liaising with the IEC also participate in this preparation. The IEC collaborates closely with the International Organization for Standardization (ISO) in accordance with conditions determined by agreement between the two organizations.

2) The formal decisions or agreements of the IEC on technical matters express, as nearly as possible, an international consensus of opinion on the relevant subjects since each technical committee has representation from all interested National Committees.

3) The documents produced have the form of recommendations for international use and are published in the form of standards, technical reports or guides and they are accepted by the National Committees in that sense.

4) In order to promote international unification, IEC National Committees undertake to apply IEC International Standards transparently to the maximum extent possible in their national and regional standards. Any divergence between the IEC Standard and the corresponding national or regional standard shall be clearly indicated in the latter.

5) The IEC provides no marking procedure to indicate its approval and cannot be rendered responsible for any equipment declared to be in conformity with one of its standards.

6) Attention is drawn to the possibility that some of the elements of this International Standard may be the subject of patent rights. The IEC shall not be held responsible for identifying any or all such patent rights.

International Standard IEC 60193 has been prepared by IEC technical committee 4: Hydraulic turbines.

This second edition of IEC 60193 cancels and replaces the first edition of IEC 60193 published in 1965, its amendment 1 (1977), IEC 60193A (1972), as well as IEC 60497 (1976) and IEC 60995 (1991).

Clauses 1 to 3 of this standard cover the scopes dealt with in the above-mentioned publications. Additional information is given in clause 4 .

The text of this standard is based on the following documents:

\begin{tabular}{|c|c|}
\hline FDIS & Report on voting \\
\hline 4/157/FDIS & 4/162/RVD \\
\hline
\end{tabular}

Full information on the voting for the approval of this standard can be found in the report on voting indicated in the above table.

Annexes $B, F, G, K, L$ and $M$ form an integral part of this standard.

Annexes $A, C, D, E, H, J, N$ and $P$ are for information only.

The committee has decided that this publication remains valid until 2004. At this date, in accordance with the committee's decision, the publication will be

- reconfirmed;

- withdrawn;

- replaced by a revised edition, or

- amended. 


\section{HYDRAULIC TURBINES, STORAGE PUMPS AND PUMP-TURBINES - MODEL ACCEPTANCE TESTS}

\section{General rules}

\subsection{Scope and object}

\subsubsection{Scope}

This International Standard applies to laboratory models of any type of impulse or reaction hydraulic turbine, storage pump or pump-turbine.

This standard applies to models of prototype machines either with unit power greater than $5 \mathrm{MW}$ or with reference diameter greater than $3 \mathrm{~m}$. Full application of the procedures herein prescribed is not generally justified for machines with smaller power and size. Nevertheless, this standard may be used for such machines by agreement between purchaser and supplier.

In this standard, the term "turbine" includes a pump-turbine operating as a turbine and the term "pump" includes a pump-turbine operating as a pump.

This standard excludes all matters of purely commercial interest, except those inextricably bound up with the conduct of the tests.

This standard is concerned with neither the structural details of the machines nor the mechanical properties of their components, so long as these do not affect model performance or the relationship between model and prototype performances.

\subsubsection{Object}

This International Standard covers the arrangements for model acceptance tests to be performed on hydraulic turbines, storage pumps and pump-turbines to determine if the main hydraulic performance contract guarantees (see 1.4.2) have been satisfied.

It contains the rules governing test conduct and prescribes measures to be taken if any phase of the tests is disputed.

The main objectives of this standard are:

- to define the terms and quantities used;

- to specify methods of testing and of measuring the quantities involved, in order to ascertain the hydraulic performance of the model;

- to specify the methods of computation of results and of comparison with guarantees;

- to determine if the contract guarantees, which fall within the scope of this standard, have been fulfilled;

- to define the extent, content and structure of the final report.

The guarantees can be given in one of the following ways:

- guarantees for prototype hydraulic performance, computed from model test results considering scale effects;

- guarantees for model hydraulic performance. 


\section{I.S. EN 60193:2000}

Moreover additional performance data (see 1.4.4) can be needed for the design or the operation of the prototype of the hydraulic machine. Contrary to the requirements of clauses 1 to 3 related to main hydraulic performance the information of these additional data given in clause 4 is considered only as recommendation or guidance to the user (see 4.1).

It is particularly recommended that model acceptance tests be performed if the expected field conditions for acceptance tests (see IEC 60041) would not allow the verification of guarantees given for the prototype machine.

This standard may also be applied to model tests for other purposes, i.e. comparative tests and research and development work.

If model acceptance tests have been performed, field tests can be limited to index tests (see IEC 60041, clause 15).

If a contradiction is found between this standard and any other standard, this standard shall prevail.

\subsection{Normative references}

The following normative documents contain provisions which, through reference in this text, constitute provisions of this International Standard. At the time of publication, the editions indicated were valid. All normative documents are subject to revision, and parties to agreements based on this International Standard are encouraged to investigate the possibility of applying the most recent editions of the normative documents indicated below. Members of IEC and ISO maintain registers of currently valid International Standards.

IEC 60041:1991, Field acceptance test to determine the hydraulic performance of hydraulic turbines, storage pumps and pump-turbines

IEC 60609:1978, Cavitation pitting evaluation in hydraulic turbines, storage pumps and pumpturbines

IEC 60609-2:1997, Cavitation pitting evaluation in hydraulic turbines, storage pumps and pump-turbines - Part 2: Evaluation in Pelton turbines

IEC 60994:1991, Guide for field measurement of vibrations and pulsations in hydraulic machines (turbines, storage pumps and pump-turbines)

IEC 61364:1999, Nomenclature of hydraulic machinery

IEC 61366 (all parts), Hydraulic turbines storage pumps and pump-turbines - Tendering documents

ISO 31-3:1992, Quantities and units - Part 3: Mechanics

ISO 31-12:1992, Quantities and units - Part 12: Characteristic numbers

ISO 468:1982, Surface roughness - Parameters, their values and general rules for specifying requirements

ISO 1438-1:1980, Water flow measurement in open channels using weirs and Venturi flumes Part 1: Thin-plate weirs 


\section{ESAI GLOBAL}

This is a free preview. Purchase the entire publication at the link below:

I.S. EN 60193 : 2000 : EN : COMBINED PDF

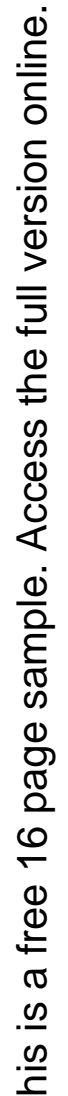

(D) Looking for additional Standards? Visit SAI Global Infostore

(D) Learn about LexConnect, All Jurisdictions, Standards referenced in Australian legislation

Need to speak with a Customer Service Representative - Contact Us 